\title{
FUTURE NEEDS FOR ENERGY STORAGE IN THE ALPINE REGION
}

\section{PRIHODNJE POTREBE PO SHRANJEVANJU ENERGIJE V ALPSKEM PROSTORU}

\author{
Marko Hočevar ${ }^{1, *}$, Lovrenc Novak ${ }^{1}$, Gašper Rak ${ }^{2}$ \\ ${ }^{1}$ University of Ljubljana, Faculty of Mechanical Engineering, Aškerčeva 6, 1000 Ljubljana, Slovenia \\ ${ }^{2}$ University of Ljubljana, Faculty of Civil and Geodetic Engineering, Jamova 2, 1000 Ljubljana, Slovenia
}

\begin{abstract}
In this paper we discuss energy storage requirements for EUSALP region in Europe. EUSALP is an Alpine region that includes the entirety Switzerland, Austria, Slovenia, and Lichtenstein, as well as parts of France, Germany, and Italy. A model is presented that facilitates the estimation of the required technical amounts of energy storage and installed power of pumped storage hydropower plants. The aim of the model is to estimate the requirements of energy storage to assist in setting guidelines for stable and reliable future electric energy supply in the EUSALP region. The model is based on currently known patterns of energy consumption and generation and available information on the future increase of renewable electric generation capacity, energy consumption, and the introduction of electromobility within all EUSALP regions. The hourly balance of generation, demand, and storage within a selected future year is assumed. The results are presented such that a mix of scenarios is addressed. Among them are installed generation capacity, installed pumped hydro storage power, selection of photovoltaic and wind electric energy generation ratio, the charging of a selected percentage of electric cars, flexible run-of-river hydro electric energy generation, import/export, generation by nuclear and backup fossil fuel sources, and a selection of disturbances. Results show that energy storage capacities must be increased by a large margin regardless of the choice of demand site management strategies or flexible electric car charging. Around a requisite 10-fold increase in pumped storage hydropower capacity is estimated, while the estimated increase in required energy storage is even higher. Daily and seasonal variations are also discussed. Further, the amount of surplus electric energy generation is presented and discussed.
\end{abstract}

Keywords: energy storage, EUSALP region, photovoltaics, wind, pumped storage hydropower plants.

\section{Izvleček}

Članek prikazuje potrebe po shranjevanju električne energije za območje regije EUSALP v Evropi. EUSALP je alpska regija, ki vključuje celotno Švico, Avstrijo, Slovenijo, Lihtenštajn in dele Francije, Nemčije in Italije. Predstavljen je model, ki omogoča oceno tehnične potrebe po shranjevanju električne energije in inštalirane moči črpalnih hidroelektrarn. Cilj modela je ocena potrebnih kapacitet za shranjevanje električne energije za pridobitev smernic za stabilno in zanesljivo prihodnjo oskrbo z električno energijo na območju EUSALP. Model temelji na trenutno znanih vzorcih porabe in proizvodnje energije ter razpoložljivih informacijah o povečanju zmogljivosti proizvodnje električne energije iz obnovljivih virov, porabi energije in uvedbi

\footnotetext{
* Stik / Correspondence: marko.hocevar@fs.uni-lj.si

(C) Hočevar M.. et al.; Vsebina tega članka se sme uporabljati v skladu s pogoji licence Creative Commons Priznanje avtorstva Nekomercialno - Deljenje pod enakimi pogoji 4.0.

(C) Hočevar M. et al.; This is an open-access article distributed under the terms of the Creative Commons Attribution - Non Commercial - ShareAlike 4.0 Licence.
}

https://doi.org/10.15292/acta.hydro.2019.03 
elektromobilnosti v območju EUSALP v prihodnosti. Pri tem je bila uporabljena urna bilanca proizvodnje, povpraševanja in shranjevanja energije v izbranem letu prihodnosti. Prikazani so rezultati različnih scenarijev, pri čemer so upoštevane že inštalirane proizvodne zmogljivosti, zgrajene črpalne hidroelektrarne, izbrana razmerja med proizvodnjo električne energije iz fotovoltaike in vetrnih elektrarn, polnjenje izbranega odstotka električnih vozil, prilagodljiva proizvodnja električne energije hidroelektrarn, uvoz in izvoz električne energije, proizvodnja električne energije nuklearnih elektrarn in rezerve virov fosilnih goriv ter izbor motenj. Rezultati kažejo potrebo po velikem povečanju kapacitet za shranjevanje električne energije, ne glede na izbiro strategij upravljanja povpraševanja ali prilagodljivega polnjenja električnih vozil. Ocenjuje se, da je potrebno približno 10-kratno povečanje zmogljivosti proizvodnje črpalnih hidroelektrarn, medtem ko je potreba po povečanju shranjene energije še večja. Pri tem obravnavamo tako dnevne in sezonske spremembe kot tudi količine presežene proizvodnje električne energije.

Ključne besede: shranjevanje energije, EUSALP, fotovoltaika, veter, črpalno akumulacijske hidroelektrarne.

\section{Introduction}

Renewable energy is energy derived from sources that are naturally replenished in short time. European legislation (EU EECS, 2011) promotes the use of renewable energy through Renewable Energy Directive and other documents. The EU has committed itself to a significant reduction in greenhouse gas emissions. Its 2020 climate and energy package has settled the 20-20-20 goals comprising a $20 \%$ reduction in greenhouse gases by 2020 compared to 1990 , as well as a $20 \%$ increase in energy efficiency and renewable energy sources at European Union level (EC EEA, 2010). EU member countries have also taken on binding national targets for raising the share of renewables in their energy consumption by 2020 under the Renewable Energy Directive (2009/28/EC). These targets vary, to reflect countries' different starting points for renewables production and ability to further increase it. In 2018 a political agreement has been reached to raise the targets for renewable energy and energy efficiency to $32 \%$ and $32.5 \%$, respectively (EEA, 2014).

Long term strategy for the EU is to become nearly carbon neutral and to reduce greenhouse gas emissions to $80-95 \%$ below 1990 levels by 2050 (EU EECS, 2011). The EU Energy Roadmap 2050 (EU EECS, 2011) explores the challenges posed by achieving the EU's decarbonization objective while at the same time ensuring the security of energy supply and its competitiveness. Several scenarios to achieve an $80 \%$ reduction in greenhouse gas emissions have been examined. All imply major changes in, for example, carbon prices, technology, and networks. All scenarios show that electricity will have to play a much greater role than now (approximately doubling its share (36-39\%) in final energy demand to (EU EECS, 2011) in 2050) and will have to contribute to the decarbonization of transport, heating, and cooling. Electricity could provide up to around $65 \%$ of energy demand from passenger cars and light-duty vehicles, as shown in various decarbonization scenarios. The share of renewable energy (RES) rises substantially in all such scenarios, achieving at least $55 \%$ in gross final energy consumption in 2050 (EU EECS, 2011). The share of RES in electricity consumption reaches $64 \%$ in a highly energy-efficient scenario and $97 \%$ in a high-renewables scenario that includes significant electricity storage to accommodate varying RES supply even at times of low demand.

Pumped hydro energy storage (PHS) is the largest energy storage technology in Europe (and indeed, worldwide). Currently, more than $50 \mathrm{GW}$ net PHS (around 30\% of global capacity) is in operation in the EU, comprising $12 \%$ of total net electrical installed capacity in the EU (Eurostat, 2017). From the point of view of the electric power system, having PHS is not only a matter of economic feasibility but of power supply reliability. This problem will gain more and more importance as the amount of non-dispatchable energies increase, as it is foreseen for the next future (EASE/EERA, 2013).

EUSALP is a European region consisting of 7 countries, of which $5 \mathrm{EU}$ are member states (all of Austria and Slovenia, and parts of France, Germany, 
and Italy) and 2 are non-EU countries (all of Liechtenstein and Switzerland), including in total 48 regions.

The study discussed in this paper led to the development of a model of energy storage requirement. The model includes currently known patterns of energy consumption and generation by various types of electric energy sources. The model is based on an hourly balance of generation, demand, and storage within a selected future year. For the future, requirements of energy storage are based on a selected percentage of RES. Requirements of increases in RES installed capacity are calculated as wind and photovoltaic (PV) factors. The model includes an envisaged increase in electric energy because of electromobility (EV). Factors of energy storage, PV, wind, and EV are defined as the ratio between future and current installed capacity and are given as a percentage; e.g.

$$
P V \text { factor }=\frac{\text { future installed power of } P V}{\text { current installed power of } P V}
$$

\section{Modelling methodology}

The model is not limited to certain scenarios of future electric energy production and consumption. Instead, the scenarios may be inserted in the model as inputs and boundary conditions, while the model will calculate the requirements for energy storage for these inputs and boundary conditions.

In the model we addressed only technical production and demand. Whenever electric energy is produced by wind or PV sources and storage capabilities are available, energy storage capabilities are used. Also, whenever there is demand and electric energy is produced, it is used to cover such demand and this energy is not stored. Electric energy is thus only stored in cases where production outpaces consumption and extant storage capabilities are not full. The prices of electric energy production including the prices of installation of power plants are not considered in any way.

In the model we have also assumed that the energy power grid transmission capacity is unlimited.

\subsection{Electric energy production}

The model was based on data available for various production sources, namely wind, $\mathrm{PV}$, run of river hydro, PHS with inflow, small hydro, other RES sources, fossil fuel power plants, and nuclear power plants (AN OVE, 2010; Bisello et al., 2017; Baumgartner and Schönberg, 2017; ENTSOE; Eurostat, 2016; Eurostat, 2017; Pfenninger and Staffell, 2016; Renewables.ninja; Staffell and Pfenninger, 2016; VBEW, 2019). As mentioned above, we have used the data of average energy production over the entire year in hourly intervals for all energy sources. Several consecutive years (1980-2016 where available) were evaluated.

Wind and PV production were averaged day by day and hour by hour over all available years. Yearly averaging was performed on individual EUSALP regions. We were able to estimate the installed power of hydro power plants (HPP) to a high degree according to the report of Baumgartner and Schönberg (2017). Discharge on the other hand cannot be easily estimated, because it varies per time of the year. The yearly variation of river water flow rate is reflected in monthly hydro power plant production diagrams. Hydrographs are included in the model for each region, because they offer information how much run-of-river hydro generation is available during selected period of the year. The minimum environmental flow rate for run of river hydro was estimated for each period of the year based on the minimum recorded hourly production of electric energy.

Production from conventional electricity sources comprises gas, coal, and nuclear thermal power plants. No differentiation was made between nuclear and other thermal power plants. The amount of conventional electricity sources was within a model selected such that the chosen percentage of RES in total production was met. Also in the model, conventional electricity sources are assumed to be always available whenever required.

We further assumed that residential, public, and industrial electric energy consumption in the future will approximately remain constant. We justify this by the reasoning that future decreases in energy consumption due to more efficient machines, 
devices, and processes will be offset by the increasing requirements of HVAC systems, and the general increase in the use of electricity due to everybody's desire to lead a comfortable life. Electric energy consumption from electromobility however increases the total electric energy consumption for scenarios that include electromobility.

\subsection{Electromobility}

In the model, electric cars can be charged in a preselected variable pattern throughout the day; however, this pattern cannot change from one day to another except for on weekends. A selectable percentage of total electric energy stored in car batteries may be taken from those car batteries when required at any time of the day (flexible charging). The model depends on a flow from an electric system into electric car batteries. We did not consider energy losses due to several charging cycles. The percentage of electric cars (number), consumption of electric energy per $100 \mathrm{~km}$, and yearly mile-age can be adjusted. We have assumed that consumption of electric energy per $100 \mathrm{~km}$ equals $20 \mathrm{kWh}$ (US EPA and US DOE, 2015) and that every electric car must charge the battery every day to the amount of energy needed to drive the average daily mileage of $39.7 \mathrm{~km}(14500 \mathrm{~km} / 365$ days).

The results presented in the next section came from the assumption that the consumption of electricity for electromobility is almost constant throughout the day. We found no reliable information on predicted future charging patterns for electromobility.

\subsection{Surplus energy production}

For modelling, wind and PV was included in the model as a source of electric energy, which is generated whenever available, therefore not flexible at all. Increasing the share of RES share leads to a situation when at selected time intervals the entire energy consumption will be covered by RES sources. With an even further increase, besides covering consumption, RES production may be too high for storage in PHS, hence leading to surplus electric energy. Surplus electric energy is energy generated by the wind and PV sources that cannot be used or stored. This may be due to insufficient pumping installed power of pumped storage hydropower plants (PSHP) or insufficient storage volumes of PHS reservoirs (energy), or both.

Data are difficult to find for individual HPP, so in the model we used the following assumptions: run of river hydro may use the water whenever required during the day or night except for the minimum environmental flow rate, required for each river; a minimum environmental flow rate must always be provided. We have set no limit on the denivelation speed of any water storage, so any rate of change in the water level in reservoirs is allowed. The maximum production power of run of river hydro is limited only by the installed power of turbines and the daily average production in run of river power plants and must be equal to historical daily averages due to the availability of water. The efficiency of the pump and turbine mode of operation was set to $\eta=$ 0.85 each, resulting in a combined efficiency of $\eta=$ $72.2 \%$, which includes all losses that appear in the storage process (transmission, transformer, generator, turbine, hydraulic and other losses etc.).

Conventional power plants cover variations in production and demand. We did not consider any possible electric system stability issues arising from a decrease in the share of conventional electricity generation. Any missing electric energy is assumed to be imported.

\section{Results and discussion}

The envisaged development of RES share in electricity production was estimated to increase linearly from $36 \%$ of total production in 2016 to an estimated $80 \%$ in 2050 . This is, however, merely an estimation, because the RES share in electricity is not set by European Union but is rather influenced by requirements in $\mathrm{CO}_{2}$ emission reduction. The list of scenarios is shown in Table 1. The EV and energy storage power are given in percentages according to the current value.

Sample amount of stored and rejected energy over an entire year for scenario 3 is shown in Figure 1 for $80 \%$ RES. The hypothetical year starts with a 
significant amount of stored energy and it ends with the same value. The total amount of energy that could be stored, however, is much larger (grey line). The amount of rejected energy is so high that it raises doubts about the viability of the current European Union approach of favoring the PV at the expense of HPP, PHS, and other energy storage solution. A modest shortage is present, requiring some import of electric energy.

The results of modelling scenario 1 are shown in Figure 2. Energy storage power for scenario 1 remains at today's level. Results show low apparent requirement for storage, which decreases with the percentage of RES in total electricity share, eventually to below $25 \mathrm{TWh}$. The low requirement for energy storage is a consequence of overgeneration during the day with RES. With over $800 \%$ of installed PV generating capacity in comparison with the current situation, during the day enough electric energy will be available and storage will only be required to cover energy demand during each night.

The results of modelling scenario 2 are shown in Figure 3. In comparison with scenario 1 we notice that, in order to maintain high RES shares, a much higher installed power of PV is required, reaching $80 \%$ RES and more than $1600 \%$ of currently installed power. Interestingly, the wind factor is not much lower than for the scenario 1 despite the set ratio of $\mathrm{PV}:$ wind $=3: 1$. Like before, scenario 2 shows a modest shortage of electric power and energy. The apparent very modest requirement for energy storage has similar roots as explained under scenario 1. Scenario 2 shows that surplus electric energy generation is enormous. Yearly over 350 TWh must be rejected in achieving an RES share of $80 \%$ due to the inability to store electric energy and because much of the electric energy is generated at an inconvenient time of the year or day. The high share of rejected electric energy from PV makes PV an extremely expensive and unattractive source of energy for achieving high RES shares.

Table 1: Selection of scenarios.

Preglednica 1: Nabor scenarijev.

\begin{tabular}{|c|c|c|c|}
\hline \multirow{2}{*}{$\mathbf{n}$} & \multicolumn{3}{|c|}{ Scenario } \\
\cline { 2 - 4 } & $\boldsymbol{P V}:$ wind & $\boldsymbol{E V}$ & $\begin{array}{c}\text { energy } \\
\text { storage } \\
\text { power }\end{array}$ \\
\hline 1 & $1: 1$ & $0 \%$ & $100 \%$ \\
\hline 2 & $3: 1$ & $0 \%$ & $100 \%$ \\
\hline 3 & $3: 1$ & $50 \%$ & $200 \%$ \\
\hline 4 & $3: 1$ & $50 \%$ & $1000 \%$ \\
\hline
\end{tabular}

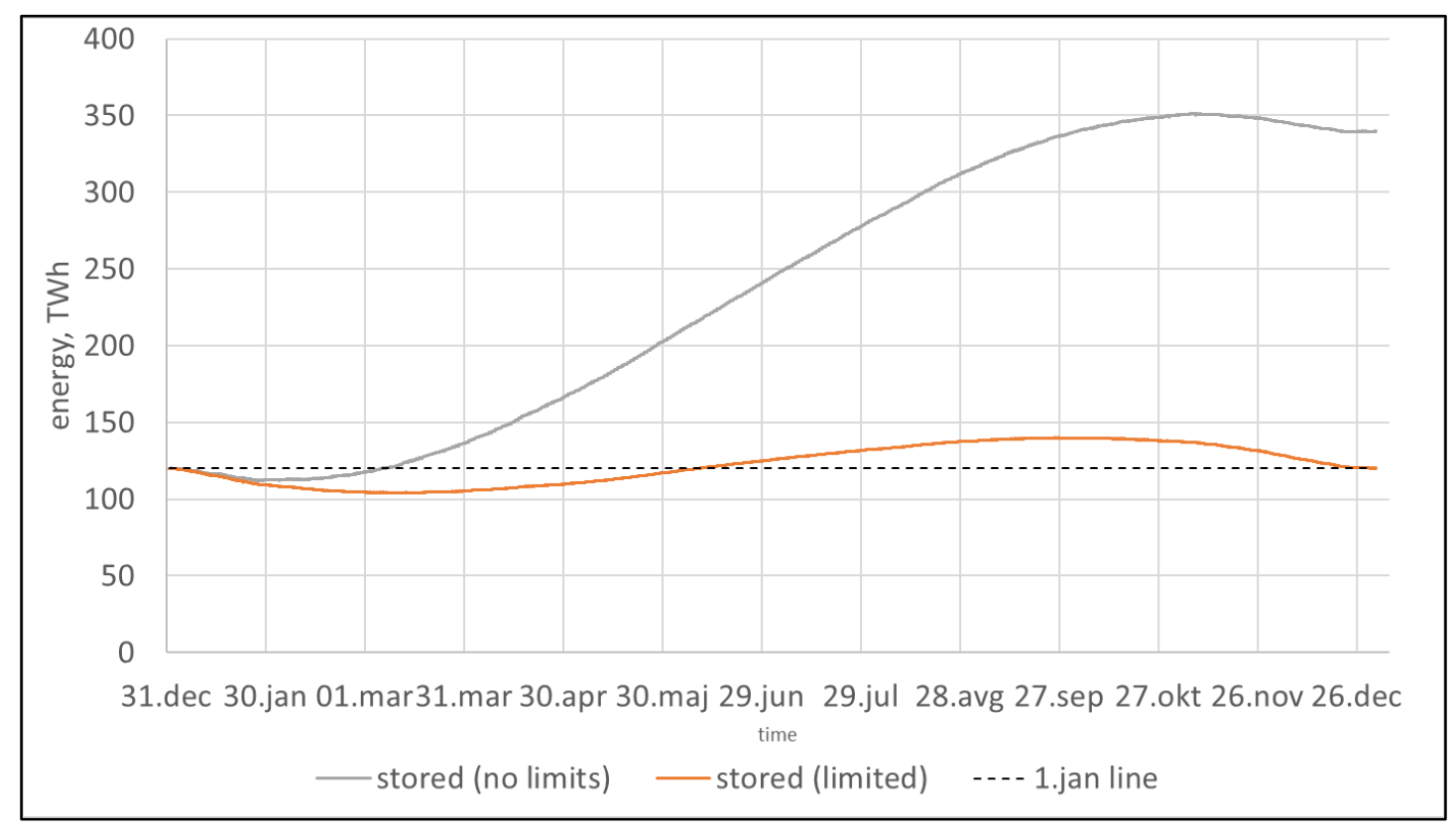

Figure 1: Amount of stored and rejected energy, sample for scenario 3 and $80 \%$ RES.

Slika 1: Količina shranjene in zavrnjene energije, vzorec za scenarij 3 in 80\% OVE. 
Hočevar M. et al.: Future needs for energy storage in the Alpine region - Prihodnje potrebe po shranjevanju energije v

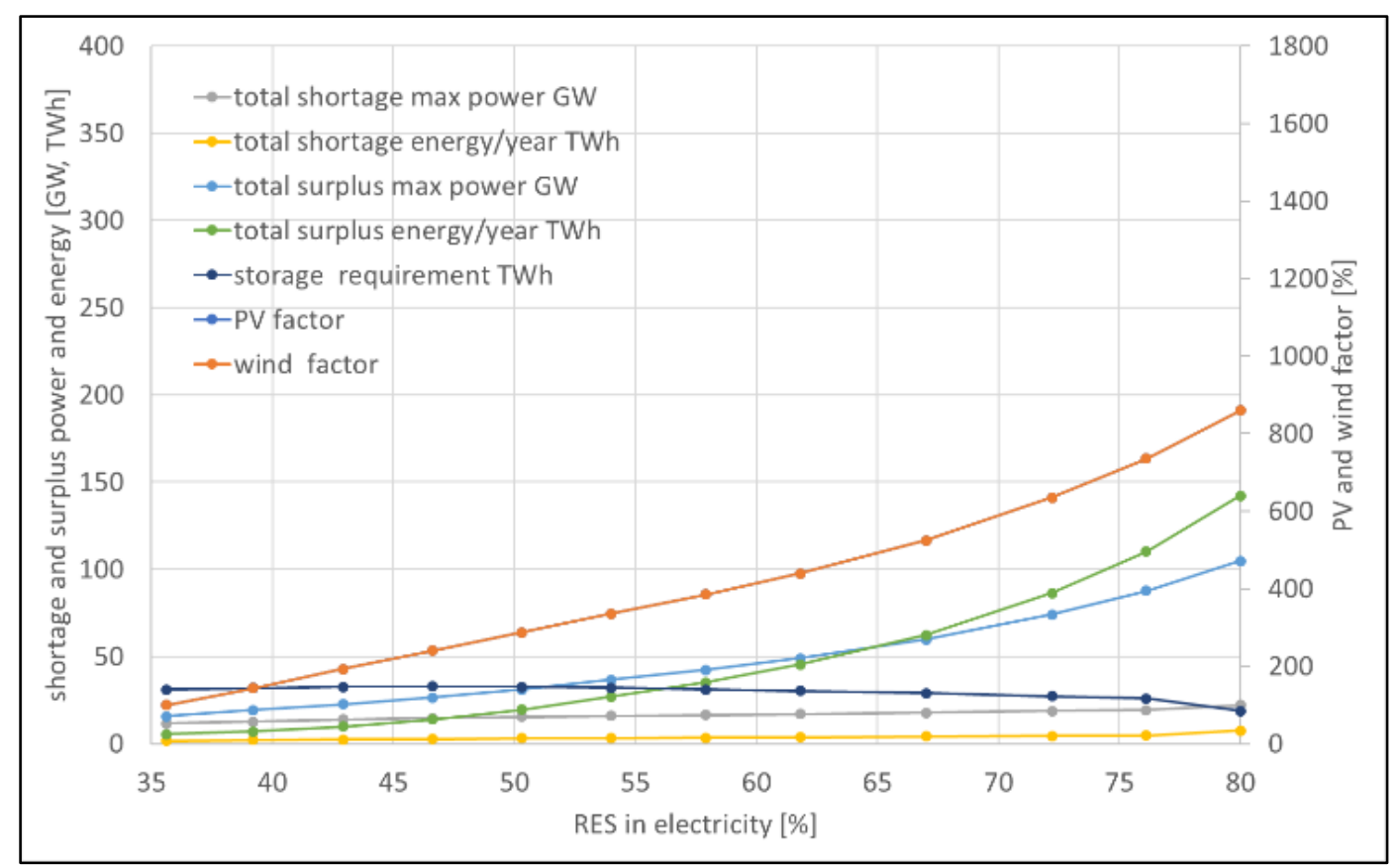

Figure 2: The requirement for energy storage for scenario 1.

Slika 2: Potreba po kapacitetah za shranjevanje energije za scenarij 1 .

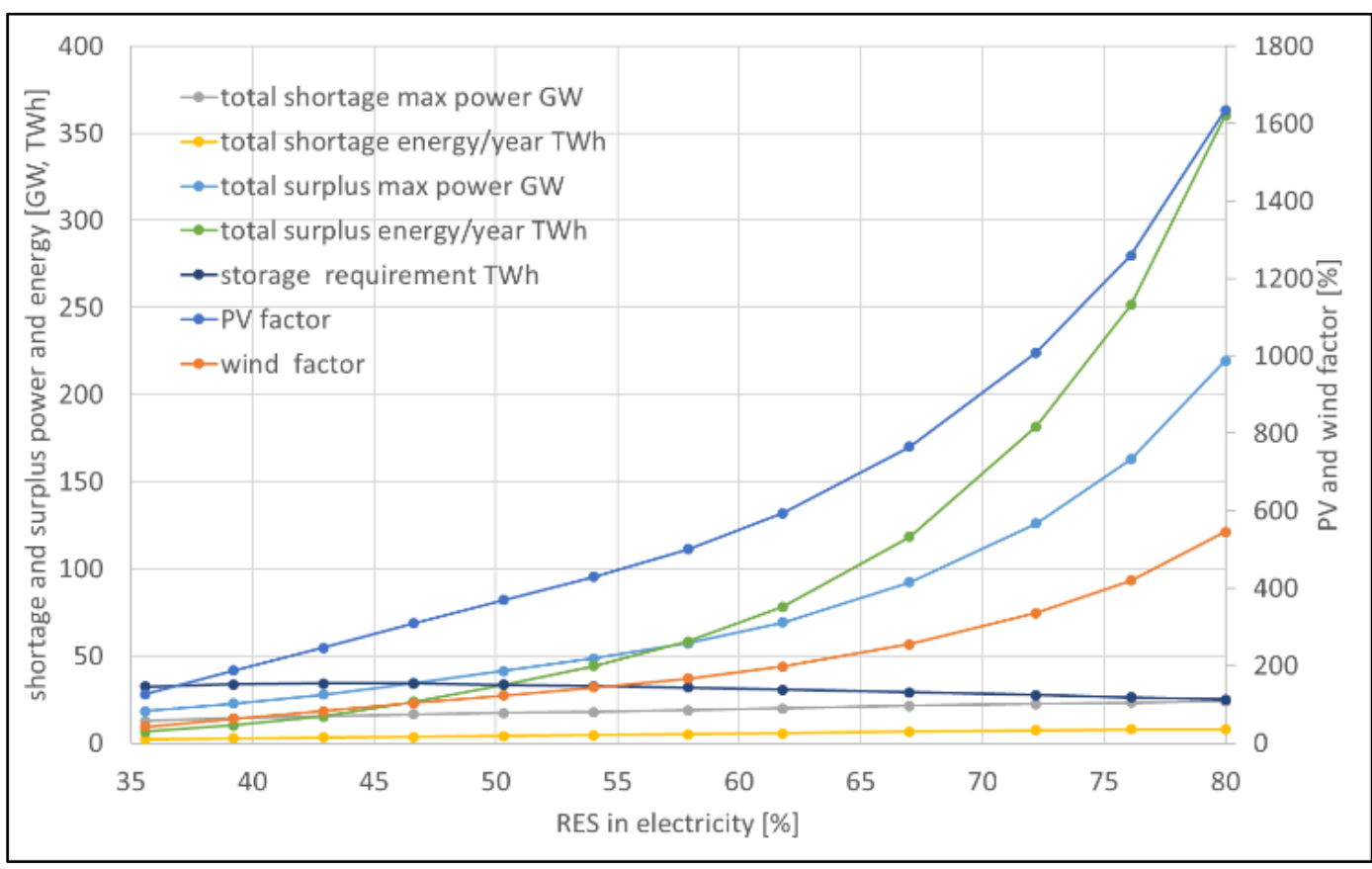

Figure 3: The requirement for energy storage for scenario 2.

Slika 3: Potreba po kapacitetah za shranjevanje energije za scenarij 2.

The results of modelling scenario 3 are shown in Figure 4. Scenario 3 is a very probable one for the future development of electric energy supply in the EUSALP region (and the entire European Union) because PV power plants are considered the most convenient to install. Despite a two-fold increase in energy storage, total surplus in electric energy production remains very high at above $350 \mathrm{TWh}$ for 
$80 \%$ RES. The PV factor for $80 \%$ RES reaches more than $1900 \%$ of current installed power. Also, the increase in the PV factor is very steep from around $65 \%$ RES, the same being true for total surplus energy. In scenario 3 the energy shortage is low due to the increase in the amount of energy storage to $200 \%$. The increase in PHS storage facilitates significantly better utilization of PV and wind power plants.

The results of modelling scenario 4 are shown in Figure 5. Here, the amount of storage was greatly increased to $1000 \%$ of the current value. We notice that the storage requirements increase with an increase in RES up to over $80 \mathrm{TWh}$. No shortage and no surplus energy were recorded, meaning that all RES electric energy production was stored and later used again when required. No surplus electric energy from PV and wind sources enables investors to sell all produced electric energy, further enabling reasonable prices for producers (also those having PV) and consumers of electric energy. PV and wind factors increase linearly with the RES share and with years. This gives the EU and EUSALP region the opportunity to more easily adapt future requirements in line with the exponentially growing PV and wind factors.

In the event of appropriately favorable public opinion, in addition to the use of stored energy in the EUSALP region, and of favorable conditions for building new PSHP in EUSALP, the region may in the future act as an energy storage provider for the broader Western, Central, and Mediterranean regions of the European Union.

The above results show the importance of stored energy to decrease the generation of surplus RES energy. Among various electric energy solutions PHS energy storage has many important advantages over competing technologies like electro-chemical battery storage or any form of mechanical energy storage. Local energy storage at a small level using PHS in the EUSALP region is also possible and should be exploited in the future. Electrochemical lithium battery storage will be implemented for very fast fluctuations in electric energy production and demand but will stay limited in installed power and capacity.

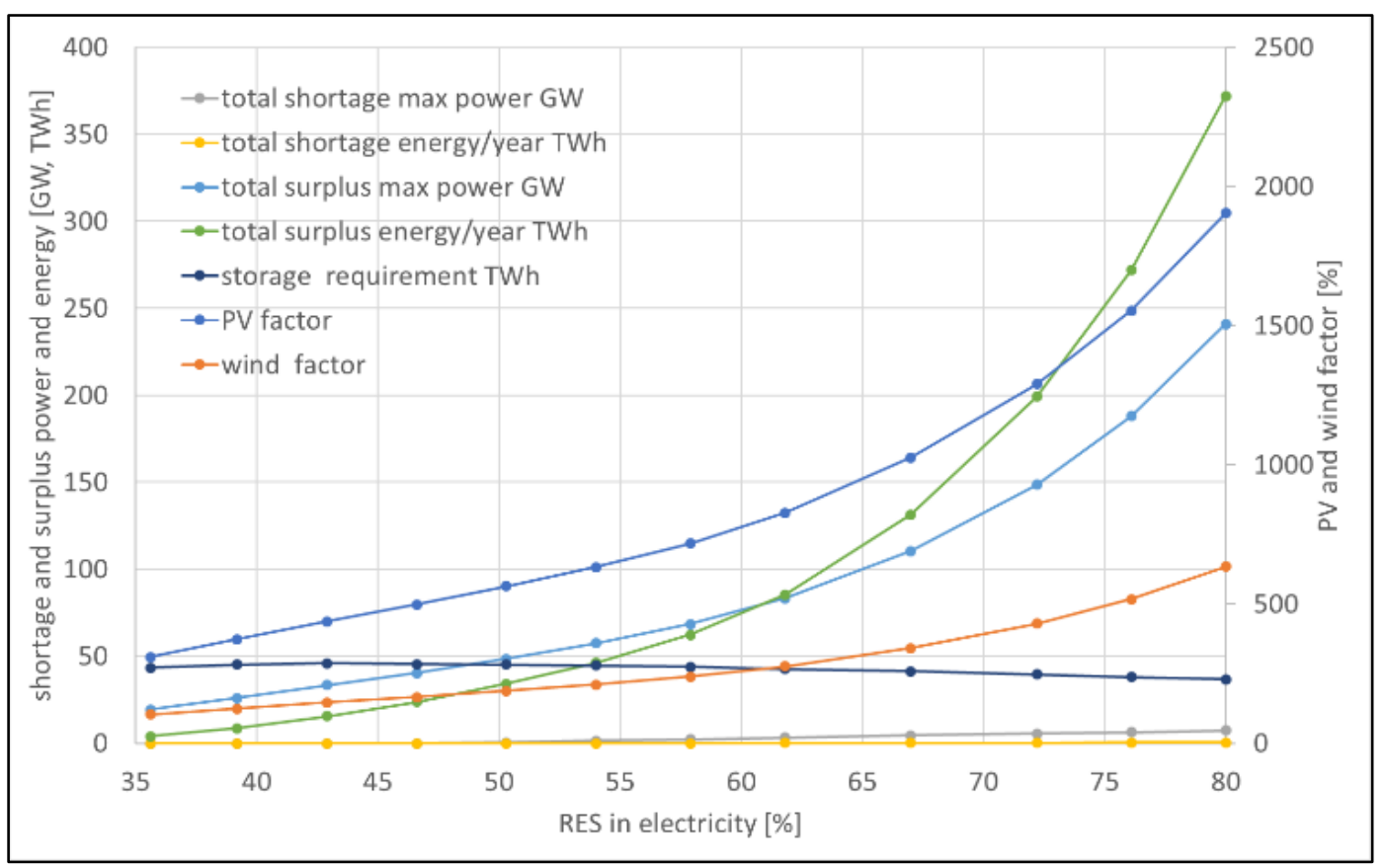

Figure 4: The requirement for energy storage for scenario 3.

Slika 4: Potreba po kapacitetah za shranjevanje energije za scenarij 3. 


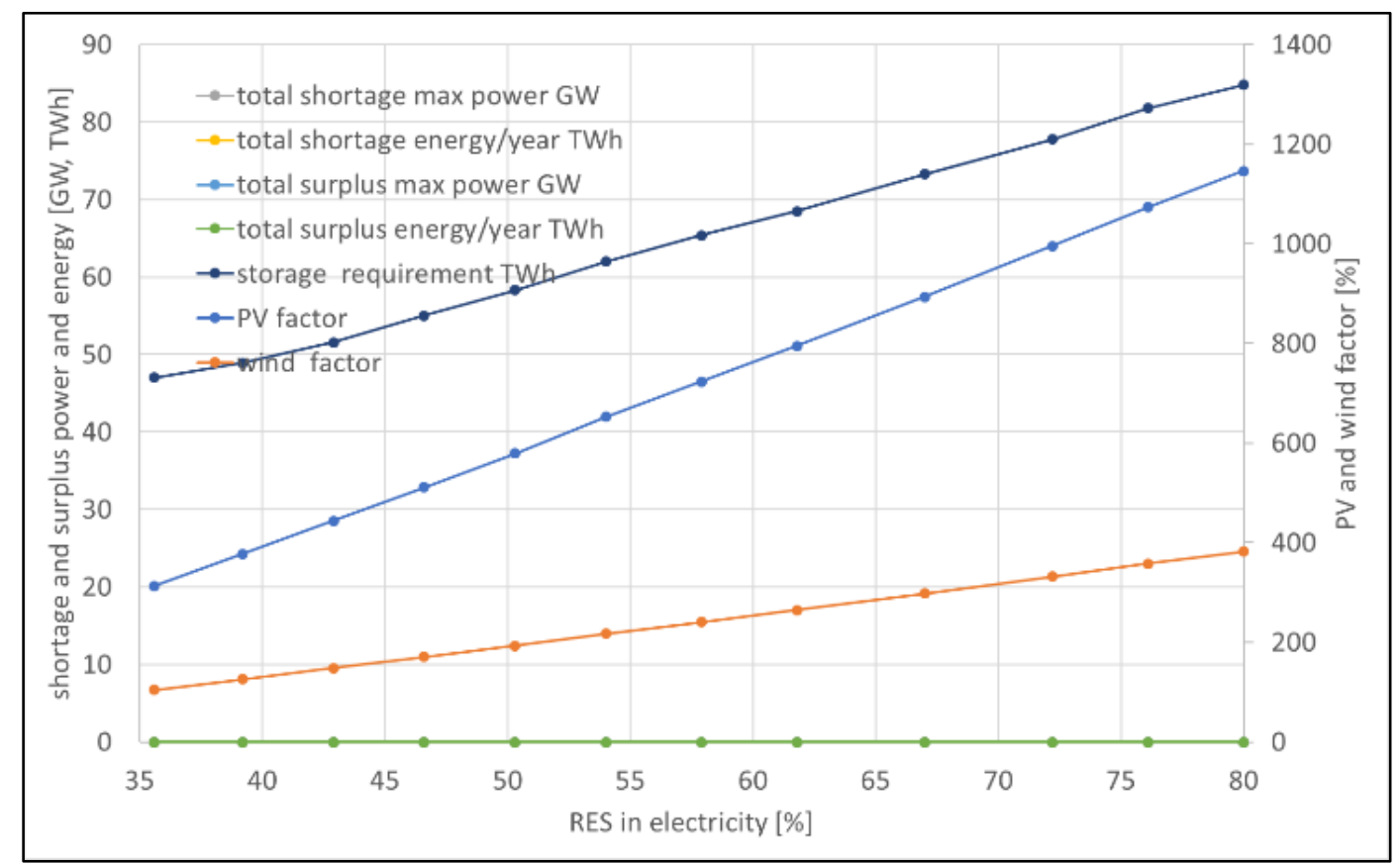

Figure 5: The requirement for energy storage for scenario 4.

Slika 5: Potreba po kapacitetah za shranjevane energije za scenarij 4.

\section{Conclusions}

Renewable energy production has increased dramatically in recent decades. This increase has been stimulated by a variety of legislative actions. The intermittent nature of electric energy generation from renewable sources will require a change in the electric storage strategy. We envisage that in the EUSALP region most energy storage will be in the form of PHS and that limited storage and generation capacities will be provided by electrochemical batteries in covering very fast fluctuations.

In the very recent past, there have been few EUfunded projects working on the rapid availability of hydropower. The requirements of electric systems dictate shortening the response to variations in the electricity system's frequency regulation from several minutes to less than a minute. Required modifications include flow instabilities reduction, mechanical design improvements, and a switch to variable frequency operation using inverters.

Scenarios with a high share of PV in RES electric energy production require excessive installed power of PV and massive surpluses in generation capacity. Using energy storage provides for much improved usage of PV and wind electric energy generation.
The low installed power of storage power plants provides for apparent low storage requirements.

The study's results offer valuable information on electric storage requirements for future stable electric energy supply.

\section{Acknowledgment}

For the work implemented in this paper we greatly acknowledge financial and other contributions from the EUSALP agency Action Group 9 with leader dr. Ulrich Santa. We also thank the Slovenian research agency ARRS for financial support from programs P2-0401 Energy engineering and P2-0180 Water Science and Technology, and Geotechnical Engineering: Tools and Methods for Process Analyses and Simulations, and Development of Technologies.

\section{References}

AN OVE - Akcijski načrt za obnovljive vire energije za obdobje 2010 - 2020 (2010) Available at: https://www.energetika-

portal.si/fileadmin/dokumenti/publikacije/an_ove/an_ov e 2010-2020_final.pdf (accessed October 2018). 
Hočevar M. et al.: Future needs for energy storage in the Alpine region - Prihodnje potrebe po shranjevanju energije $\mathrm{v}$ Alpskem prostoru

Acta hydrotechnica 32/56 (2019), 35-43, Ljubljana

Baumgartner, A., Schönberg, M. (2017). Status and Future of Alpine Hydropower, report.

Bisello, A., Tomasi, S., Garegnani, G., Scaramuzzino, C., Segata, A., Vetto-rato, D., Sparber, W. (2017). EUSALP Energy Survey 2017, report. Available at: https://www.alpine-region.eu/publications/eusalpenergy-survey-2017 (accessed December 2018).

EASE/EERA (2013). Energy Storage Technology Development Roadmap towards 2030, Joint EASE/EERA recommendations for a European Energy Storage Technology Development Roadmap towards 2030. Available at: http://ease-storage.eu/easeeeraenergy-storage-technology-development-roadmaptowards-2030/ (accessed January 2019).

EC EEA (2010) Energy 2020 - A strategy for competitive, sustainable and secure energy, COM (2010) 639. Available at: https://ec.europa.eu/energy/sites/ener/files/documents/2 012_energy_roadmap_2050_en_0.pdf (accessed March 2019).

EC Eurostat (2016). Share of renewables in energy consumption in the EU reached $17 \%$ in 2016. Website: https://ec.europa.eu/eurostat/web/products-pressreleases/-/8-25012018-AP (accessed October 2018).

EC Eurostat (2017a). Energy from renewable sources. Website:

https://ec.europa.eu/eurostat/web/energy/data/shares (accessed December 2018).

EC Eurostat (2017b). Eurostat statistics explained. Website: http://ec.europa.eu/eurostat/statisticsexplained/images/c/c8/EU28-NONFOSSIL-

ELECTRICAL-CAPACITY-2015.png (accessed December 2018).

EEA (2009). Directive 2009/28/EC of the European Parliament and of the Council of 23 April 2009 on the pro-motion of the use of energy from renewable sources and amending and subsequently repealing Directives 2001/77/EC and 2003/30/EC. Available at: https://eurlex.europa.eu/legal-

content/EN/TXT/PDF/?uri=CELEX:32009L0028\&from =en (accessed March 2019).

EEA (2014). The conclusions adopted by the European Council at the European Council meeting (23 and 24 October 2014), EUCO 169/14. Available at: https://www.consilium.europa.eu/uedocs/cms_data/docs /pressdata/en/ec/145397.pdf (accessed February 2019).

ENTSOE (2019). European Network of Transmission System Operators for Electricity. Website: https://www.entsoe.eu/ (data retrieved from 1.11.2018 to 31.1.2019)

EU EECS (2011). Energy Roadmap 2050. Available at: https://ec.europa.eu/energy/sites/ener/files/documents/2 012_energy_roadmap_2050_en_0.pdf (accessed March 2019).

Pfenninger, S., Staffell, I. (2016). Long-term patterns of European PV output using 30 years of validat-ed hourly reanalysis and satellite data. Energy 114, 1251-1265. https://doi.org/10.1016/j.energy.2016.08.060.

Renewables.ninja. Simulations of hourly power output from wind and solar PV farms. Website: https://www.renewables.ninja/ (accessed January 2019).

Staffell, I., Pfenninger, S. (2016). Using Bias-Corrected Reanalysis to Simulate Current and Future Wind Power Output. Energy 114, 1224-1239. https://doi.org/10.1016/j.energy.2016.08.068.

US EPA and US DOE (2015). Compare side by side: 2013 Nissan Leaf/2014 Nissan Leaf/2015 Nissan Leaf/2016 Nissan Leaf (24 kW-hr battery pack)/2016 Nissan Leaf (30 kW-hr battery pack). Available at: https://www.fueleconomy.gov/feg/Find.do?action=sbs\&

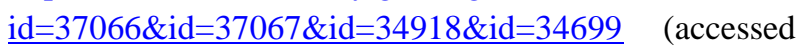
December 2018).

VBEW (2019). Zahlen und Fakten $\rightarrow$ Stromwirtschaft Website: $\quad$ https://www.vbew.de/vbew/zahlen-undfakten/stromwirtschaft/ (data retrieved from 1 November 2018 to 31 January 2019). 